\title{
АКТИВНОСТЬ АЛЬФА-2-МАКРОГЛОБУЛИНА В СЛЕЗНОЙ ЖИДКОСТИ ПРИ ПРОЛИФЕРАТИВНОЙ ДИАБЕТИЧЕСКОЙ РЕТИНОПАТИИ
}

\author{
Нероев В.В., Чеснокова Н.Б., Павленко Т.А., Охоцимская Т.Д., Безнос О.В., Лисовская О.А. \\ ФГБУ «НМИЦ глазных болезней им. Гельмгольца» Минздрава РФ, г. Москва
}

\begin{abstract}
АКТУАЛЬНОСТb: Альфа2-макроголобулин (a2-МГ) принимает участие в запуске как нейродегенеративных процессов, так и неоваскуляризации сетчатки, т.е. процессах, которые являются ключевыми в патогенезе пролиферативной диабетической ретинопатии (ПДР).

ЦЕЛЬ: определение активности а2-МГ в слезной жидкости (СЖ) больных ПДР для обнаружения связи уровня активности а2-МГ в слезе с наличием патологического процесса в сетчатке.

МАТЕРИАЛЫ И МЕТОДЫ: обследовали 19 больных с сахарным диабетом II типа с ПДР (мужчин - 9 , женщин - 10; возраст от 32 до 75 лет). Контрольной группой послужили 14 добровольцев без сахарного диабета и офтальмопатологии, сопоставимые по возрасту с группой больных с ПДР.

Всем пациентам проводили стандартное офтальмологическое обследование и оптическую когерентную томографию. СЖ забирали из обоих глаз утром с помощью стерильной фильтровальной бумаги.

Определение активности а2-МГ основано на том, что комплекс а2-МГ с трипсином сохраняет протеолитическую активность по отношению к низкомолекулярным субстратам, в том числе к N-бензоил-DLаргинин-п-нитроанилиду, и на эту активность не влияет ингибитор трипсина из бобов сои. Активность a2-МГ выражали в нмоль/мин*мл. Измерения проводили на фотометре для микропланшет Synergy MX (BioTek, США).
\end{abstract}

Достоверность различий определяли с помощью U-критерия Манна-Уитни. Различия считали достоверными при $\mathrm{p}<0,05$.

РЕЗУЛЬТАТЫ И ОБСУЖДЕНИЕ: У пациентов С ПДР обнаружено статистически достоверное повыше-

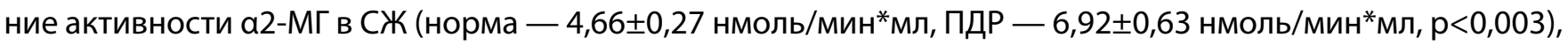
в среднем в 1,5 раза выше нормы.

Полученные данные свидетельствуют о том, что при ПДР у большинства больных происходит существенное увеличение активности а2-МГ в СЖ. Данных по активности а2-МГ в СЖ больных ПДР в доступной литературе мы не обнаружили.

a2-МГ - это белок с очень высокой молекулярной массой и поэтому плохо проникает в тканевые жидкости из кровотока. В тканевые жидкости, в том числе и в слезу, он поступает из окружающих клеток. В слезу он может поступать из роговицы, в клетках которой, в том числе в эпителии происходит его синтез, из клеток конъюнктивы, а также из слезных желез. Известно, что состав слезы отражает не только метаболические процессы, протекающие в тканях, ею омываемых, но состояние внутренних структур глаза, в том числе сетчатки, что можно объяснить взаимодействием нервных и гуморальных путей регуляции.

Таким образом, при ПДР происходит увеличение активности а2-МГ в СЖ. Учитывая важную патогенетическую роль а2-МГ в процессах неоваскуляризации сетчатки и гибели ганглиозных клеток, можно полагать, что дальнейшее изучение особенностей изменения активности а2-МГ при ПДР в СЖ позволит более точно определять прогноз и направленность медикаментозной терапии этого заболевания. 